УДК 657.42:001.891:637.52:005.936.3

DOI: $10.15673 /$ fie.v10i4.1133

\author{
Ощепков О.П. \\ кандидат економічних наук, доцент \\ кафедра обліку та аудиту \\ E-mail: moto47rod@gmail.com
}

\author{
Чебан М.М. \\ магістрант \\ кафедра обліку та аудиту \\ E-mail:marissa77751@gmail.com
}

\author{
Магденко С.O. \\ старший викладач \\ кафедра економіки промисловості \\ Одеська національна академія харчових технологій \\ вул. Канатна, 112, м. Одеса, Україна, 65039 \\ E-mail: maglana1@meta.ua
}

\title{
ОРГАНІЗАЦІЯ І МЕТОДИКА ПРОВЕДЕННЯ АНАЛІЗУ СТАНУ ТА РУХУ ОСНОВНИХ ЗАСОБІВ НА М'ЯСОПЕРЕРОБНИХ ПІДПРИЄМСТВАХ
}

У статті розглянуто організаційно-методичні умови до проведення аналізу стану, руху та динаміки основних засобів на прикладі м'ясопереробних підприємств України. Розглянуто різні підходи до визначення сутності основних засобів та їх зв'язок з основним капіталом. В результаті дослідження наведено власне тлумачення сутності основних засобів. Використовуючи загальні методики аналізу основних засобів проведено аналіз руху основних засобів, аналіз придатності і зносу основних засобів з урахуванням питомої ваги активної частини основних засобів. В результаті проведеного аналізу було виявлено нераціональне використання основних засобів, про що свідчать низькі коефіцієнти оновлення основних засобів і коефіцієнти вибуття. За результатами розрахунків коефіцієнтів придатності і зносу виявлено, що терміни корисного використання активної частини в структурі основних засобів значно перевищують нормативні, які рекомендовані в Податковому кодексі України, що приводить до додаткових витрат на їх поточні та середні ремонти. Також це робить неможливим впроваджувати інтенсивну і інноваційну політику розвитку підприємства.

Ключові слова: основні засоби, методика аналізу зносу, придатності та оновлення основних засобів, коефіцієнт динаміки, коефіцієнт реальної вартості основних засобів

This work is licensed under a Creative Commons Attribution 4.0 International License http://creativecommons.org/licenses/by/4.0/

Постановка проблеми та її зв'язок з важливими науковими та практичними завданнями. Питання підвищення ефективності функціонування і розвитку підприємств залежать від наявності і стану факторів виробництва. В першу чергу, це відноситься до основних засобів. Від рівня забезпечення основними засобами, їх кількістю та якістю, технологією їх взаємозв'язку буде залежить організація виробництва продукції, iï конкурентоспроможність на внутрішньому і зовнішньому ринках.

Своєчасний аналіз наявності, стану і руху основних засобів дозволить контролювати ефективність їх використання та визначати заходи для подальшого ефективного їх руху та впливу на кінцеві результати діяльності підприємства. Особлива увага повинна приділятись до технологічної структури основних

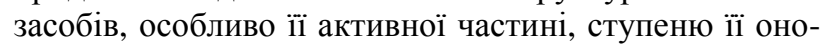
влення та інноваційності.

Разом 3 тим, м'ясопереробні підприємства використовують власні потужності лише на 40-60 відсотків і підвищення ефективності їх функціонування і розвитку за рахунок як екстенсивного, так $\mathrm{i}$ інтенсивного факторів використання основних засобів, має обмеження, які обумовлені низкою факторів:
- по-перше, це обмеженість сировинних ресурсів і боротьба за них;

- по-друге, це обмеженість споживчого попиту в країні і боротьба за гривню споживача.

На важливість врахування цих факторів для м'ясопереробних підприємств вказують й автори Л.О. Андрєєва та O.I. Лисак, які підкреслюють, що для м'ясопереробних підприємств особливу увагу слід приділяти питанням співвідносин 3 контрагентамипостачальниками сировини для забезпечення надійного процесу виробництва та торговельними підприємствами [1, с,143].

Все вищезазначене свідчить про те, що тема $€$ актуальною і потребує подальшого розгляду, пошуку нових рішень щодо використання основних засобів.

Аналіз останніх публікацій та проблеми. Загальним питанням теорії, організації та методики аналізу основних засобів, їх сутності, функцій присвячені роботи Ф.Ф. Бутинця, М.Т. Білухи, М.Г Чумаченка, І.Ф. Прокопенка, В.В. Сопка, А.М. Ткаченка. Серед іноземних вчених, які займались дослідженням теорії основного капіталу, його відтворення та ефективності використання можна назвати, починаючи від А. Сміта і Д. Рікардо, К. Маркса, Ж. Сея та А. Ма- 
ршалла до П. Самуельсона та інших сучасних вчених. Разом 3 тим, питання організації і методики аналізу в умовах кризового стану та формування сучасного ринкового середовища досліджено недостатньо, в тому числі нормативно-правове регулювання використання і відтворення основних засобів. Недоліками в роботах останніх публікацій $є$ недостатнє дослідження галузевого аспекту аналізу основних засобів, особливо мало приділяється уваги частковим показникам (наприклад, коефіцієнту змінності), які впливають на узагальнюючі показники ефективності їх використання (фондовіддачу та фондорентабельність).

Серед вчених, які досліджували використання і відтворення основних засобів в галузях АПК, можна виділити роботи В. Андрійчука, М. Герасимчука, І. Лукінова, П.Т. Саблука, І. Швець та інших. Останні роботи, в яких досліджується аналіз основних засобів на підприємствах м'ясопереробної галузі, належать авторам О.В. Сгоровій, А.Л. Коляді, К. А. Колосовій, О.В. Коровчук, О.І. Лисак, А.М. Стельмащук та авторам цієї статті. Разом з тим, автори досліджують більше узагальнюючі показники без проведення факторного аналізу зміни цих показників в сучасних умовах та впливу зміни технологічної структури основних засобів, яка суттєво може впливати на ефективність їх використання та фінансові результати діяльності підприємств в цілому.

Формування цілей дослідження. Визначити вплив зміни показників руху та стану основних засобів м'ясопереробних підприємств на можливість їх оновлення та впровадження інтенсивної та інноваційної моделі розвитку підприємств.

Виклад основних результатів та їх обгрунтування. Дослідження процесу проведення аналізу основних засобів потребує розгляду їх сутності i співвідношення 3 поняттями «основні фонди» і «основний капітал», оскільки різні автори при розрахунку однакових по суті показників використовують різні поняття. Так, більшість авторів пов'язують основні засоби 3 характеристикою капіталу. Дійсно, при переході до міжнародних стандартів обліку, необхідно буде переходити до категорії «основний капітал», або «постійний капітал». Разом 3 тим, і цей взаємозв'язок різні автори трактують неоднаково. Так, до поняття «основного капіталу», як накопиченої частини матеріальних благ або запасів, підходять Ж. Міль і А. Сміт, останній характеризує його як запас продукції, що приносить прибуток або за допомогою якого створюються нові блага [2], тобто чіткого виділення основних засобів ще не відбувається. Розвиваючи теорію капіталу, К. Маркс відмічав, що економічні епохи відрізняються не тим, що виробляють, а тим, якими засобами виробництва i, в першу чергу, він виділяв засоби праці, які представляють «костномускульную систему» [3, с.190- 191] підприємства, від стану якої залежить ефективність праці.

Пол Самуельсон вважав основний капітал як «блага длительного пользования, употребляющиеся в качестве ресурсов в будущем производстве, одновременно являясь ресурсом и продуктом, и на которого распространяется право собственности» [4].

В російській літературі «основні фонди» розглядаються як «засоби праці». «Основные фонды - это средства труда, которые многократно участвуют в производственном процессе, сохраняя при этом свою натуральную форму, постепенно изнашиваясь, переносят свою стоимость по частям на вновь создаваемую продукцию. К ним относят фонды со сроком службы более одного года и стоимостью более 100 минимальных месячных заработных плат» [5].

T.М. Рогуленко та Є.О. Сгорова під основними засобами вважають «совокупность средств труда в материально-вещественном и стоимостном выражении, которые используются в процессе производства продукта, выполнения работ и оказания услуг, имеющих срок полезного использования больше одного операционного цикла и постепенно переносящие свою стоимость на новую продукцию в виде амортизационных отчислений» [6].

Тобто, можна сказати, що основний капітал, основні фонди і основні засоби розкривають сутність одного й того ж - засобів праці.

Взаємозв'язок між основними фондами і основними засобами М.В. Афанасьєв і А.В. Гончаров характеризують так: «Беручи участь в створенні товару, засоби виробництва виступають як виробничі фонди» [7, с.56].

С.В. Мочерний характеризує основні засоби через основний капітал як частину постійного капіталу, яка складається з вартості засобів праці [8].

Існуюча національна система рахунків в Україні передбачає спеціальні стандарти обліку, методологія побудови яких базується на міжнародних стандартах. Для характеристики основних засобів та бухгалтерського обліку використовують П(С)БО № 7 «Основні засоби», які враховують міжнародні стандарти МСФЗ № 16. Відповідно до стандартів П(С)БО № 7, «Основні засоби - це матеріальні активи, що підприємство утримує 3 метою використання їх у процесі виробництва або постачання товарів, надання послуг, здачі в оренду іншим особам або для здійснення адміністративних і соціально-культурних функцій, очікуваний термін корисного використання (експлуатації) яких більш одного року (або операційного циклу, якщо він більш року) [9].

Враховуючи різні підходи до характеристики основних засобів, нами пропонується наступне поняття основних засобів. Основні засоби - це форма основного капіталу, які приймають участь в виробничому процесі тривалий період, не змінюючи власну натуральну форму протягом періоду корисного використання, і переносять свою вартість на вироблений продукт частинами у формі суми амортизації. Тобто основні засоби характеризуються трьома особливостями:

- незмінною натурально-речовою формою протягом терміну їх корисного використання;

- участю у виробничому процесі тривалий час (більше одного року);

- перенесенням своєї вартості на готовий продукт частинами у формі сум амортизаційних відраху- 
вань.

Тому особливо важливим є процес організації та підготовки для проведення аналізу основних засобів, який передбачає:

- визначення забезпеченості підприємств основними засобами;

- їх розміщення в окремих підрозділах за елементами та структурою;

- визначення встановлених і не встановлених основних засобів;

- встановлення діючих або не діючих основних засобів.

Нами досліджується їх технологічна структура 3 встановленням терміну корисного використання, визначеною нормою амортизації відповідно до облі- кової політики підприємства. Рішення цих питань дозволить провести аналіз динаміки, руху основних засобів, оцінити їх склад і стан. На підставі результатів аналізу можна буде зробити висновки та запропонувати шляхи подальшого покращення використання основних засобів.

Для проведення аналізу стану і руху основних засобів нами було обрано п'ять м'ясопереробних підприємств різних за вартістю основних засобів, обсягом виробленої продукції і фінансовим результатом.

Наявність і рух основних засобів за два роки наведено в табл.1.

Таблиця 1

Вартість основних засобів м'ясопереробних підприсмств за 2016-2017 роки (тис. грн.) *

\begin{tabular}{|c|c|c|c|c|c|c|c|c|}
\hline \multirow[t]{2}{*}{ Підприємство } & \multicolumn{2}{|c|}{$\begin{array}{c}\text { Вартість основних } \\
\text { засобів на початок } \\
\text { року }\left(\mathrm{O} 3_{п р}\right)\end{array}$} & \multicolumn{2}{|c|}{$\begin{array}{c}\text { Введено протягом } \\
\text { року }\left(\mathrm{O}_{\text {вв }}\right)\end{array}$} & \multicolumn{2}{|c|}{$\begin{array}{c}\text { Виведено протягом } \\
\text { року }\left(\mathrm{O} 3_{\text {вив }}\right)\end{array}$} & \multicolumn{2}{|c|}{$\begin{array}{c}\text { Вартість основних } \\
\text { засобів на кінець } \\
\text { року }\left(\mathrm{O} 3_{\text {кр }}\right) \\
\end{array}$} \\
\hline & 2016 & 2017 & 2016 & 2017 & 2016 & 2017 & 2016 & 2017 \\
\hline $\begin{array}{l}\text { ПрАТ "Український } \\
\text { бекон" }\end{array}$ & 453401 & 467194 & 19290 & 600731 & 5497 & 0 & 467194 & 1067925 \\
\hline $\begin{array}{l}\text { ПАТ "Івано- } \\
\text { Франківський } \\
\text { м’ясокомбінат" }\end{array}$ & 311614 & 317476 & 5952 & 0 & 90 & 118 & 317476 & 317358 \\
\hline $\begin{array}{l}\text { ПрАТ "Козятинський } \\
\text { м’ясокомбінат }\end{array}$ & 108103 & 120786 & 1294 & 10610 & 301 & 13 & 120786 & 131383 \\
\hline $\begin{array}{l}\text { ПрАТ "Богодухівсь- } \\
\text { кий м'ясокомбінат" }\end{array}$ & 19614 & 20684 & 1160 & 1820 & 90 & 110 & 20684 & 22394 \\
\hline ПП Фірма "ГАРМАШ" & 57179 & 60458 & 3279 & 1719 & - & - & 60458 & 62177 \\
\hline
\end{tabular}

* Інформація за даними офіційного сайту «Відомості Національної комісії з цінних паперів та фондового ринку» [10]

Дані табл.1 свідчать про загальну тенденцію до зростання вартості основних засобів на підприємствах і незначну частину виведення основних засобів 3 експлуатації. Наступним кроком розрахуємо коефіцієнти їх руху та динаміки - це коефіцієнти оновлення, вибуття та динаміки.

Коефіцієнт оновлення основних засобів $\left(K_{\text {он }}\right)$ характеризує інтенсивність введення в дію нових основних засобів. Він показує частку введених основних засобів за визначений період у загальній вартості основних засобів на кінець звітного періоду. Коефіuі - єнт вибуття основних засобів $\left(K_{\text {виб }}\right)$ характеризує рівень інтенсивності їх вибуття зі сфери виробництва. Своєчасне вибуття старої техніки та заміна ї̈ новою, підкреслює Т.А. Кулаковська, є важливий спосіб їх оновлення, який дозволяє підтримувати високу питому вагу нового обладнання [10, с.258]. Коефіuієнт динаміки основних засобів $\left(K_{\partial}\right)$ характеризує рівень приросту основних засобів або окремих його груп за певний період. Результати розрахунків наведено в табл. 2 .

Коефіціснти руху і динаміки основних засобів*

\begin{tabular}{|l|c|c|c|c|c|c|c|c|c|}
\hline \multirow{2}{*}{ Підприємство } & \multicolumn{2}{|c|}{$\begin{array}{c}\text { Коефіцієнт } \\
\text { оновлення }\left(\mathrm{K}_{\text {он }}\right)\end{array}$} & \multicolumn{2}{|c|}{$\begin{array}{c}\text { Коефіцієнт } \\
\text { вибуття }\left(\mathrm{K}_{\text {виб }}\right)\end{array}$} & \multicolumn{2}{c|}{$\begin{array}{c}\text { Коефіцієнт } \\
\text { динаміки }\left(\mathrm{K}_{\text {д }}\right)\end{array}$} & \multicolumn{3}{|c|}{$\begin{array}{c}\text { Абсолютне відхилення } \\
\text { коефіцієнтів }\end{array}$} \\
\cline { 2 - 11 } & 2016 & 2017 & 2016 & 2017 & 2016 & 2017 & оновлення & вибуття & динаміки \\
\hline $\begin{array}{l}\text { ПрАТ "Українсь- } \\
\text { кий бекон" }\end{array}$ & 0,0413 & 0,5625 & 0,0121 & 0,0000 & 1,0304 & 2,2858 & 0,5212 & $-0,0121$ & 1,2554 \\
\hline $\begin{array}{l}\text { ПАТ "Івано- } \\
\text { Франківський } \\
\text { м'ясокомбінат" }\end{array}$ & 0,0187 & 0,0000 & 0,0003 & 0,0004 & 1,0188 & 0,9996 & $-0,0187$ & 0,0001 & $-0,0192$ \\
\hline $\begin{array}{l}\text { ПрАТ "Козятинсь- } \\
\text { кий м'ясокомбінат }\end{array}$ & 0,1075 & 0,0808 & 0,0028 & 0,0001 & 1,1173 & 1,0877 & $-0,0267$ & $-0,0027$ & $-0,0296$ \\
\hline
\end{tabular}




\begin{tabular}{|c|c|c|c|c|c|c|c|c|c|}
\hline & & & & & & & & Продов & ення табл.2 \\
\hline \multirow[t]{2}{*}{ Підприємство } & \multicolumn{2}{|c|}{$\begin{array}{c}\text { Коефіцієнт } \\
\text { оновлення }\left(\mathrm{K}_{\mathrm{он}}\right)\end{array}$} & \multicolumn{2}{|c|}{$\begin{array}{c}\text { Коефіцієнт } \\
\text { вибуття }\left(\mathrm{K}_{\text {вибб }}\right)\end{array}$} & \multicolumn{2}{|c|}{$\begin{array}{c}\text { Коефіцієнт } \\
\text { динаміки }\left(\mathrm{K}_{д}\right)\end{array}$} & \multicolumn{3}{|c|}{$\begin{array}{c}\text { Абсолютне відхилення } \\
\text { коефіцієнтів }\end{array}$} \\
\hline & 2016 & 2017 & 2016 & 2017 & 2016 & 2017 & оновлення & вибуття & динаміки \\
\hline $\begin{array}{l}\text { ПрАТ "Богодухів- } \\
\text { ський } \\
\text { м'ясокомбінат" }\end{array}$ & 0,0561 & 0,0813 & 0,0046 & 0,0053 & 1,0546 & 1,0827 & $-0,0252$ & 0,0007 & 0,0281 \\
\hline $\begin{array}{l}\text { ПП Фірма } \\
\text { "ГАРМАШ" }\end{array}$ & 0,0542 & 00276 & - & - & 1,0573 & 1,0284 & $-0,0255$ & - & $-0,0309$ \\
\hline
\end{tabular}

*Розраховано авторами за даними форм звітності підприємств

Результати розрахунків коефіцієнтів показали, що у більшості підприємств коефіцієнти оновлення в 2017 році зменшились, за винятком ПрАТ

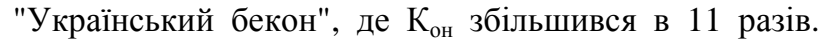

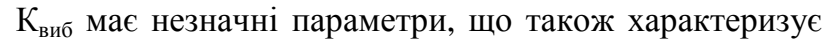
незадовільну політику використання основних засобів. $\mathrm{K}_{\text {д }}$ має позитивну тенденцію в обох роках, за винятком в 2017 році на ПАТ "Івано-Франківський м'ясокомбінат".
В цілому можна зробити висновок, що показники руху погіршились, про що вказують від'ємні значення абсолютного їх відхилення.

Наступним кроком проаналізуємо стан основних засобів на підприємствах за допомогою коефіцієнтів придатності $\left(\mathrm{K}_{\text {пр }}\right)$, зносу $\left(\mathrm{K}_{3 н}\right)$ та реальної вартості $\left(K_{\text {реал}}\right)$, які будуть розраховані на підставі даних, які наведені в табл.3.

Характеристика основних засобів на кінець року (млн. грн.)*

\begin{tabular}{|c|c|c|c|c|c|c|c|c|c|}
\hline \multirow[t]{2}{*}{ Підприємство } & \multicolumn{3}{|c|}{$\begin{array}{c}\text { Первісна вартість на кінець } \\
\text { року }\left(\text { ПВ }_{\text {кр }}\right)\end{array}$} & \multicolumn{3}{|c|}{$\begin{array}{c}\text { Залишкова вартість на } \\
\text { кінець року }\left(3 \mathrm{~B}_{\text {кр }}\right)\end{array}$} & \multicolumn{3}{|c|}{$\begin{array}{c}\text { Вартість майна на кінець } \\
\text { року }\left(\mathrm{BM}_{\mathrm{\kappa p}}\right)\end{array}$} \\
\hline & 2015 & 2016 & 2017 & 2015 & 2016 & 2017 & 2015 & 2016 & 2017 \\
\hline $\begin{array}{l}\text { ПрАТ "Український бе- } \\
\text { кон" }\end{array}$ & 453,4 & 467,2 & 1067,9 & 203,0 & 175,3 & 338,3 & 1193,8 & 1551,8 & 1281,6 \\
\hline $\begin{array}{l}\text { ПАТ "Івано-Франківський } \\
\text { м’ясокомбінат" }\end{array}$ & 311,6 & 317,5 & 317,4 & 85,1 & 87,5 & 84,8 & 1055,1 & 779,1 & 882,0 \\
\hline $\begin{array}{l}\text { ПрАТ "Козятинський } \\
\text { м’ясокомбінат }\end{array}$ & 108,1 & 120,8 & 131,4 & 79,0 & 86,4 & 90,6 & 141,6 & 156,1 & 198,4 \\
\hline $\begin{array}{l}\text { ПрАТ "Богодухівський } \\
\text { м'ясокомбінат" }\end{array}$ & 19,6 & 20,7 & 22,4 & 8,5 & 8,6 & 9,7 & 13,2 & 14,2 & 15,9 \\
\hline ПП Фірма "ГАРМАШ" & 57,18 & 60,46 & 62,18 & 29,0 & 30,1 & 29,4 & 55,8 & 60,9 & 65,2 \\
\hline
\end{tabular}

* Інформація за даними офіційного сайту «Відомості Національної комісії з цінних паперів та фондового ринку» [10]

Таблиця 4

Коефіціснти стану основних засобів*

\begin{tabular}{|l|c|c|c|c|c|c|c|c|c|}
\hline \multirow{2}{*}{ Підприємство } & \multicolumn{3}{|c|}{ Коефіцієнт придатності } & \multicolumn{3}{c|}{ Коефіцієнт зносу (Кзн) } & \multicolumn{3}{|c|}{$\begin{array}{c}\text { Коефіцієнт реальної вар- } \\
\text { тості О3 (Креал) }\end{array}$} \\
\cline { 2 - 11 } & 2015 & 2016 & 2017 & 2015 & 2016 & 2017 & 2015 & 2016 & 2017 \\
\hline $\begin{array}{l}\text { ПрАТ "Український бе- } \\
\text { кон" }\end{array}$ & 0,4478 & 0,3753 & 0,3167 & 0,5522 & 0,6247 & 0,6833 & 0,1701 & 0,1130 & 0,2639 \\
\hline $\begin{array}{l}\text { ПАТ "Івано- } \\
\text { Франківський } \\
\text { м'ясокомбінат" }\end{array}$ & 0,2731 & 0,2757 & 0,2671 & 0,7269 & 0,7243 & 0,7329 & 0,0807 & 0,1124 & 0,0961 \\
\hline $\begin{array}{l}\text { ПрАТ "Козятинський } \\
\text { м'ясокомбінат }\end{array}$ & 0,7310 & 0,7150 & 0,6898 & 0,2690 & 0,2850 & 0,3102 & 0,5580 & 0,5532 & 0,4569 \\
\hline $\begin{array}{l}\text { ПрАТ "Богодухівський } \\
\text { м'ясокомбінат" }\end{array}$ & 0,4325 & 0,4148 & 0,4310 & 0,5675 & 0,5852 & 0,5690 & 0,6446 & 0,6047 & 0,6065 \\
\hline ПП Фірма "ГАРМАШ" & 0,5067 & 0,4974 & 0,4734 & 0,4933 & 0,5026 & 0,5266 & 0,5190 & 0,4831 & 0,4612 \\
\hline
\end{tabular}

*Розраховано авторами за даними форм звітності підприємств

Kоефіuієнт зносу характеризує ту частку вартості основних засобів, що списано на витрати виробництва в попередніх періодах в формі суми амортизаційних відрахувань. Коефіuієнт придатнос- $m i$ відображає частку не перенесеної на створюваний продукт вартості та відображає можливості подальшого виробництва. 
Одним з основних показників, що характеризує ефективність руху і стану основних засобів $є$ коефіцієнт реальної вартості основних засобів у майні підприємства ( $\left.\mathrm{K}_{\text {реал }}\right)$ [12], який відображає питому вагу вартості основних засобів в сумі майна підприємства (валюті балансу).

За результатами розрахунків можна зробити висновки про термін корисного використання основних засобів та порівняти їх з рекомендованими термінами, які наведені в ст. 145 Податкового кодексу України [13].

Результати розрахунку наведених коефіцієнтів свідчать про те, що ступінь придатності основних засобів менше, ніж 50 \%, за винятком ПрАТ "Козятинський м'ясокомбінат", де частка придатності складає від 73 до $69 \%$, що дозволяє йому підтримувати достатньо високі темпи оновлення основних засобів, високий рівень активної частини основних засобів. Цьому також сприяє високій рівень частки реа- льної вартості основних засобів в структурі майна підприємства. Достатньо стабільна позиція на ПП Фірма «Гармаш» - на рівні 50\% і коефіцієнт реальної вартості в структурі майна також знаходиться біля 50\%. Низькі коефіцієнти придатності спостерігаються на ПАТ «Український бекон» та ПАТ «ІваноФранківський м'ясокомбінат».

Вважається, якщо коефіцієнт реальної вартості основних виробничих засобів у майні підприємства сягає критичної позначки $(0,2$ - 0,3), то реальний виробничий потенціал підприємства буде низьким i треба терміново шукати кошти для виправлення становища [12]. Проте, ми вважаємо доцільно розраховувати цей коефіцієнт по вартості активної частини основних засобів (без вартості земельних ділянок, будівель та споруджень). Нормативний інтервал пропонуємо залишити на тому ж рівні - 0,2-0,3.

Розрахунки коефіцієнту реальної вартості основних засобів по активній частині наведені в табл.5.

Таблиця 5

Коефіціснти реальної вартості основних засобів по активній частині*

\begin{tabular}{|l|c|c|c|c|c|c|c|c|c|}
\hline \multirow{2}{*}{ Підприємство } & \multicolumn{3}{|c|}{$\begin{array}{l}\text { Питома вага активної } \\
\text { частини О3 на кінець року, } \\
\text { частки* }\end{array}$} & \multicolumn{2}{|c|}{$\begin{array}{l}\text { Залишкова вартість } \\
\text { актиної частини О3 на } \\
\text { кінець року, млн. грн* }\end{array}$} & \multicolumn{3}{|c}{$\begin{array}{c}\text { Коефіцієнт реальної } \\
\text { вартості О3 по активній } \\
\text { частині на кінець року }\end{array}$} \\
\cline { 2 - 10 } & 2015 & 2016 & 2017 & 2015 & 2016 & 2017 & 2015 & 2016 & 2017 \\
\hline $\begin{array}{l}\text { ПрАТ "Український } \\
\text { бекон" }\end{array}$ & 0,6221 & 0,5910 & 0,6028 & 126,3 & 103,6 & 203,9 & 0,1058 & 0,0668 & 0,1591 \\
\hline $\begin{array}{l}\text { ПАТ "Івано- } \\
\text { Франківський } \\
\text { м’ясокомбінат" }\end{array}$ & 0,0337 & 0,0907 & 0,0786 & 2,9 & 7,9 & 6,7 & 0,0027 & 0,0102 & 0,0076 \\
\hline $\begin{array}{l}\text { ПрАТ "Козятинський } \\
\text { м'ясокомбінат }\end{array}$ & 0,2668 & 0,2606 & 0,3093 & 21,1 & 22,5 & 28,0 & 0,1489 & 0,1442 & 0,1413 \\
\hline $\begin{array}{l}\text { ПрАТ "Богодухівський } \\
\text { м'ясокомбінат" }\end{array}$ & 0,3768 & 0,3056 & 0,3827 & 3,2 & 2,6 & 3,7 & 0,2429 & 0,1848 & 0,2321 \\
\hline ПП Фірма "ГАРМАШ" & 0,5758 & 0,5913 & 0,5825 & 16,7 & 17,8 & 17,1 & 0,2989 & 0,2918 & 0,2630 \\
\hline
\end{tabular}

* Інформація за даними офіційного сайту «Відомості Національної комісії з цінних паперів та фондового ринку» [10]

На підставі наведених даних про залишкову вартість активної частини основних засобів, можна визначити термін повного корисного їх використання та спрогнозувати можливості інноваційного розвитку підприємства. Тільки два підприємства мають реальну вартість активної частини основних засобів в межах норми: ПП Фірма "ГАРМАШ" і ПрАТ та "Богодухівський м'ясокомбінат". В нашому прикладі термін повної амортизації коливається від 5 років на ПрАТ "Богодухівський м'ясокомбінат" до 12-15 років на інших підприємствах.

На нашу думку, тільки врахування реальної вартості активної частини основних засобів, в залежності від технологічної їх структури, може надавати оцінку ефективності використання основних засобів. Використання основних засобів більше визначеного терміну їх корисного використання приводить до додаткових витрат для їх підтримки в робочому стані, це різного роду поточного і середнього ремонту. Все це буде погіршувати фінансовий стан підприємства.

Тобто ми можемо зробити висновок, що інтенсивність і інноваційність на підприємствах м'ясопереробної галузі використовуються недостатньо; прискорений метод амортизації активної частини основних засобів практично не використовується. Також, спостерігаються суттєві перевищення термінів корисного використання активної частини основних засобів, які рекомендовані Податковим кодексом для даної групи - 5 років [13].

Висновки та перспективи подальшого дослідження. Проведено теоретичне дослідження сутності основних засобів і характеристики їх стану та організаційно-методичних умов проведення економічного аналізу стану, руху та динаміки основних засобів. За даними статистичної звітності п'яти м'ясопереробних підприємств проведено економічний аналіз стану, руху та динаміки основних засобів, за результатами якого виявлено: 
- частка активної частини основних засобів поступово зменшується;

- активна частина основних засобів використовується більше запропонованого терміну корисного використання, що приводить до додаткових витрат на їх поточні та середні ремонти, які можуть негативно вплинути на фінансові результати діяльності підприємств;

- коефіцієнт вибуття має незначні значення, що може свідчити про неефективну систему оновлення основних засобів та перешкоджає впровадженню інноваційних та інтенсивних моделей розвитку м'ясопереробних підприємств;

- показник реальної вартості основних засобів, який відображає частку залишкової вартість в структурі валюти балансу, тільки по одному підприємству знаходиться на достатньому рівні.
Для порівняння коефіцієнтів реальної вартості основних засобів різних підприємств важливо враховувати ступінь інтенсивності їх використання, яка впливає на рівень їх фізичного зносу. Тобто від коефіцієнта використання виробничої потужності та коефіцієнта змінності роботи обладнання та машин. Разом 3 тим, методикою нарахування амортизації це не враховується. Для цього може бути використаний виробничий метод нарахування амортизації.

Подальші дослідження будуть пов'язані з визначенням впливу i аналізом оновлення основних засобів для розробки напрямів підвищення ефективності розвитку підприємства.

\section{Література}

1. Андрєєва Л.О., Лисак О.І. Аналітична оцінка діяльності м'ясопереробних підприємств регіону //Інноваційна економіка. 2016. №1-2(61). С.141-146

2. Смит А. Исследование о природе и причинах богатства народов [Електронний ресурс]. URL: https://www.gumer.info/bibliotek_Buks/Econom/smit/ smit_1.pdf (дата звернення 18.09.2018 p.)

3. Маркс К. Капитал. Критика политической экономии / К.Маркс; пер. с нем. И.И.СкворцоваСтепанова. Москва: Политиздат. 1973. Т.1. 907 с. (рус.яз.)

4. Самуэльсон П. Экономика / П. Смуэльсон; пер. с англ. Антонової В.Д. та ін. Москва: НПО «Алгон». 1993. Т.1. 340 с. (рус.яз.)

4. Основные фонды предприятия [Електронний ресурс].

URL:http://www.ereport.ru/articles/firms/osnfond.htm (дата звернення 20.09.2018 p.)

6. Рогуленко Т.М., Егорова Е.О. Сущность основных средств как объекта бухгалтерского учета // Вестник университета. 2017. № 1.C. 129-134. URL:https://cyberleninka.ru/article/v/suschnost-osnovnyh-sredstv-kakobekta-buhgalterskogo-ucheta (дата звернення 24.09.2018 p.)

7. Афанасьєв М.В., Гончаров А.Б. Економіка підприємства: навч.-метод. посіб. для самост. вивч. дисц. / За ред. проф. М.В. Афанасьєва. Харків: ВД «ІНЖЕК». 2003. 410 с.

8. Мочерний С.В. Економічна теорія: посіб. для студ. вищих закладів освіти. Київ: Вид. центр "Академія". 1999. 592 с.

9. Основні засоби: Положення (стандарт) бухгалтерського обліку 7: затв. наказом Мінфіну від 20.10.99 p. № 246 за станом на 18.06.2015 p. URL: http://zakon.rada.gov.ua/laws/show/z0288-00 (дата звернення 15.09.2018 p.)

10. Відомості Національної комісії з цінних паперів та фондового ринку: [Веб-сайт]. Київ, 2018. URL: https://smida.gov.ua/db/emitent (дата звернення 29.09.2018 р.)

11. Кулаковська Т.А. Вимір стану та оцінка якості відтворення основних фондів промислового підприємства. Методи проведення спеціальних економічних розрахунків: навч. посіб. / під ред. д.е.н., проф. П.В.Осіпова. Одеса: Друк. 2010. С.236 - 256

12. Поддєрьогін A.M. Фінанси підприємств. [Електронний pecypc]. URL: http://studentbooks.com.ua/content/view/522/54/1/2/ (дата звернення 18.09.2018 p.)

13. Податковий кодекс України від 02.12.2010 року № 2755-VI за станом на 28.07.2018 р. [Електронний pecypc]. URL: http://zakon.rada.gov.ua/laws/show/2755-17 (дата звернення 22.09.2018 p.)

Стаття надійшла 10.10.2018 Стаття прийнята до друку 24.10.2018 Доступно в мережі Internet 29.12.2018 


\section{Ощепков А.П.}

кандидат экономических наук, доцент кафедра учёта и аудита

E-mail: moto47rod@gmail.com
Чебан М.Н.

магистрант

кафедра учёта и аудита

E-mail:marissa77751@gmail.com

Магденко С.A.

старший преподаватель

кафедра экономики промышленности

Одесская национальная академия пищевых технологий

ул. Канатная, 112, г. Одесса, Украина,65039

E-mail:maglana1@meta.ua

\section{ОРГАНИЗАЦИЯ И МЕТОДИКА ПРОВЕДЕНИЯ АНАЛИЗА СОСТОЯНИЯ И ДВИЖЕНИЯ ОСНОВНЫХ СРЕДСТВ НА МЯСОПЕРЕРАБАТЫВАЮЩИХ ПРЕДПРИЯТИЯХ}

В статье рассмотрены организационные и методические подходы к проведению анализа состояния, движения и динамики основных средств на примере мясоперерабатывающих предприятий. Рассмотрены различные подходы к характеристике основных средств, начиная от Адама Смита до современных авторов. Большинство авторов связывают основные средства с основным капиталом, а также основные средства с основными фондами. В результате обобщения разных точек зрения, нами предложено следующее определение основных средств.

Для проведения анализа движения и обновления основных средств определены задания и способы организации проведения анализа и определены показатели, при помощи которых будут определяться результаты движения и обновления основных средств.

На основе общих методик проведен анализ движения основных средств при помощи коэффициентов ввода, выбытия и обновления. Результаты анализа показали, что на предприятиях очень низкий коэффиццинт выбытия, что негативно сказывается на результатах обновления основных средств и свидетельствует о нерациональном использовании основных средств.

Анализ годности и износа основных средств предложено провести с учетом удельного веса активной части основных средств. В результате проведенного анализа было выявлено, что на предприятиях коэффициент годности составляет менее пятидесяти процентов. Также было установлено, что срок полезного использования значительно превышает нормативный, который рекомендовано в Налоговом кодексе Украины. При проведении анализа установлено, что коэффрициент реальной стоимости основных средств как по полной их стоимости, так и по активной их части, находятся в критическом интервале.

Это удлиняет срок использования морально устаревших основных средств и делает невозможным внедрение интенсивной и инновационной политики развития мясоперерабатывающих предприятий.

Ключевые слова: основные средства, методика анализа износа, годности и обновления основных средств, коэффициент динамики, коэффрициент реальной стоимости основных средств

\section{Oshchepkov 0.}

Ph.D., Associate Professor

Department of Accounting and Auditing

E-mail: moto47rod@gmail.com

\section{Magdenko S}

Assistant

Department of Industrial Economics

Odessa National Academy of Food Technologies

Kanatna str., 112, Odesa, Ukraine, 65039

E-mail:maglana1@meta.ua

\section{ORGANIZATION AND METHODOLOGY FOR REALIZATION OF THE ANALYSIS OF CONDITION AND MOVEMENT OF FIXED ASSETS AT MEAT-PROCESSING ENTERPRISES}

The article considers the organizational and methodological approaches for realization of the analysis of condition, movement and dynamics of fixed assets on the example of meat-processing enterprises. 
Various approaches to characteristics of fixed assets, ranging from Adam Smith to modern authors, have been considered. Most authors associate fixed assets with capital assets, as well as fixed assets with capital funds. As a result of the generalization of different points of view, we have proposed the following definition of fixed assets.

For the realization of the analysis of the movement and updating of fixed assets, tasks and ways of organizing the analysis have been defined as well as indicators with the help of which the results of the movement and updating of fixed assets will be determined.

Based on general methods, the analysis of the movement of fixed assets was carried out using the index of input, retirement and updating. The results of the analysis showed that enterprises have a very low index of retirement, which negatively affects the results of the updating of fixed assets and indicates an irrational use of fixed assets.

Analysis of suitability and depreciation of fixed assets was proposed to carry out taking into specific gravity the percentage of the active part of fixed assets. As a result of the analysis that was carried out, it was found that the index of suitability at the enterprises is less than fifty percent. It was also found that the useful life significantly exceeds the standard, which is recommended in the Tax Code of Ukraine. During the analysis, it was established that the index of real value of fixed assets, both by their full cost and by their active part, is in the critical interval.

This fact lengthens the use of obsolete fixed assets and makes it impossible to implement an intensive and innovative policy of the development of meat processing enterprises.

Keywords: fixed assets, methods of analysis of depreciation, suitability and updating of fixed assets, dynamic factor, index of real value of fixed assets.

\section{References}

1. Andrieieva, L. O., \& Lysak, O. I. (2016). Analìičcna ocìnka diâl'nostì m'âsopererobnih pìdpriêmstv regìonu. İnnovacìjna Ekonomika, ((1-2) 61), 141-146.

2. Smit, A. Issledovanie o prirode i pričinah bogatstva narodov. Retrieved September 18, 2018, from https://www.gumer.info/bibliotek_Buks/Econom/smit/smit_1.pdf

3. Marks, K. (1973). Kapital. Kritika političeskoj èkonomii (Vol. 1) (I. I. Skvortsova-Stepanova, Trans.). Moskva: Politizdat.

4. Samuelson, P. (1993). Èkonomika (Vol. 1) (V. D. Antonova, Trans.). Moskva: NPO «Algon».

5. Osnovnye fondy predpriâtiâ. Retrieved September 20, 2018, from

http://www.ereport.ru/articles/firms/osnfond.htm

6. Rogulenko, T. M., \& Egorova, E. O. (2017). Suŝnost' osnovnyh sredstv kak ob'ekta buhgalterskogo učeta. Vestnik Universiteta, (1), 129-134. Retrieved September 24, 2018, from https://cyberleninka.ru/article/v/suschnost-osnovnyh-sredstv-kak-obekta-buhgalterskogo-ucheta

7. Afanasiev, M. V., \& Honcharov, A. B. (2003). Ekonomika pidpriêmstva (M. V. Afanasiev, Ed.). Kharkiv: $\mathrm{VD}$ «ÌNŽEK».

8. Mochernyi, S. V. (1999). Ekonomična teoriâ. Kyiv: Vid. centr "Akademîa".

9. Osnovnì zasobi: Položennâ (standart) buhgalters'kogo obliku 7: Zatv. nakazom Mìnfìnu vìd 20.10.99 r. №

246 za stanom na 18.06.2015 r. (2015). Retrieved September 15, 2018, from http://zakon.rada.gov.ua/laws/show/z028800

10. Vìdomostì Nacìonal'noï komìsiï z cìnnih paperìv ta fondovogo rinku. (2018). Retrieved September 29,

2018, from https://smida.gov.ua/db/emitent

11. Kulakovska, T. A. (2010). Vimir stanu ta ocìnka âkostì vìdtvorennâ osnovnih fondìv promislovogo pidpriêmstva. Metodi provedennâ special'nih ekonomičnih rozrahunkìv (P. V. Osìpov, Ed.). Odesa: Druk.

12. Poddierohin, A. M. Fìnansi pìdpriêmstv. Retrieved September 18, 2018, from http://studentbooks.com.ua/content/view/522/54/1/2/

13. Podatkovij kodeks Ukraïni vid 02.12.2010 roku № 2755-VI za stanom na 28.07.2018 r. (2018). Retrieved September 22, 2018, from http://zakon.rada.gov.ua/laws/show/2755-17

Received 10 October 2018

Approved 24 October 2018

Available in Internet 29.12.2018

Цитування згідно ДСТУ 8302:2015

Ощепков О.П., Чебан М.М., Магденко С.О. Організація і методика проведення аналізу стану та руху основних засобів на м'ясопереробних підприємствах // Економіка харчової промисловості. 2018. Т. 10, Вип. 4. С. 58-65. doi: 10.15673/fie.v10i4.1133

Cite as APA style citation

Oshchepkov O., Cheban M., \& Magdenko S. (2018). Organization and methodology for realization of the analysis of condition and movement of fixed assets at meat-processing enterprises. Food Industry Economics, 10(4), 58-65;

doi: 10.15673/fie.v10i4.1133 